\title{
Concentration of minerals in the hoof horny capsule of healthy and lame dairy cows
}

\section{Concentração de minerais no estojo córneo do casco em vacas leiteiras sadias e com claudicação}

\author{
Antonio Amaral Barbosa ${ }^{1 *}$; Gabriela Bueno Luz ${ }^{2}$; Viviane Rohrig Rabassa ${ }^{3}$; \\ Marcio Nunes Corrêa ${ }^{3}$; Charles Ferreira Martins ${ }^{3}$; \\ Francisco Augusto Burkert Del Pino ${ }^{4}$
}

\begin{abstract}
The aim of this study was to evaluate the mineral concentrations in the hoof horny capsule of healthy Holstein cows and cows with hoof problems associated with laminitis. Twenty-one multiparous Holstein cows with an average production of $24 \mathrm{~L}$ of milk/day, reared with semi-extensive nutritional management, were studied. The animals were evaluated and divided into two groups based on their locomotion score (LS, range: 0 to 4). LS greater than 2 indicated laminitis-associated lesions (lame cow group: LC), and LS $=0$ indicated cows without laminitis (CWL). A sample of $30 \mathrm{~mm}^{2}$ was collected from the hoof horny capsule at the abaxial wall to evaluate the concentrations of calcium, phosphorus, zinc, and magnesium. Calcium blood concentration was also evaluated. The LC group had lower magnesium concentration $(\mathrm{P}=0.008)$ and showed a trend $(\mathrm{P}=0.06)$ for lower calcium concentration compared to healthy animals (CWL), even though all animals were normocalcemic. The concentration of other minerals did not differ between the LC and CWL group. In conclusion, the magnesium concentration in the hoof horny capsule was lower in cows with lesions associated with laminitis, while phosphorus and zinc concentrations were not affected. The relationship between hoof lesions and calcium concentration requires further investigation.
\end{abstract}

Key words: Bovine. Hoof. Macrominerals. Microminerals. Aseptic pododermatitis.

\section{Resumo}

O objetivo deste trabalho foi avaliar as concentrações de minerais no tecido córneo de vacas leiteiras da raça Holandês saudáveis e com afecções podais associadas à laminite. Foram utilizados 21 bovinos, fêmeas, multíparas, da raça Holandês, com produção média de 24 litros de leite por dia, submetidas a manejo semi extensivo de alimentação. Os animais foram avaliados quanto ao seu escore de locomoção (EL) e divididos em dois grupos: EL acima de dois, apresentando lesões associadas à laminite (vacas com laminite - VCL); e EL igual a zero (vacas sem laminite - VSL). Foi realizada uma coleta de tecido córneo com aproximadamente $30 \mathrm{~mm}^{2}$ de área da região abaxial da muralha do casco, a partir destas amostras foi realizada análise de cálcio, fósforo, zinco e magnésio. Foi realizada coleta de sangue para análise dos níveis de cálcio. Os animais do grupo VCL apresentaram níveis de magnésio

\footnotetext{
${ }^{1}$ Médico Veterinário, Doutorando em Veterinária, Universidade Federal de Pelotas, UFPel, Pelotas, RS, Brasil. E-mail: antoniobarbosa.vet@hotmail.com

2 Médica Veterinária, Mestranda em Zootecnia, UFPel, Pelotas, RS, Brasil. E-mail: gabrielabluz.veterinaria@gmail.com

${ }^{3}$ Profs. Drs., Departamento de Clínicas Veterinária, Universidade Federal de Pelotas, UFPel, Pelotas, RS, Brasil. E-mail: vivianerabassa@gmail.com; marcio.nunescorrea@gmail.com; martinscf68@yahoo.com.br

${ }^{4}$ Prof. Dr., Departamento de Bioquímica, UFPel, Pelotas, RS, Brasil. E-mail: fabdelpino@gmail.com

* Author for correspondence
} 
menores $(\mathrm{P}=0,008)$, já com o cálcio foi observado aproximação da significância $(\mathrm{P}=0,06)$ para menores concentrações desse mineral quando comparado às vacas sadias (VSL) apesar de todos os animais serem normocalcêmicos. Os demais minerais avaliados não apresentaram diferença entre grupos. Em conclusão, vacas com lesões associadas à laminite apresentam menores concentrações de magnésio no tecido córneo digital, sem variação nas concentrações de fósforo e zinco. A relação entre lesões podais e os níveis de cálcio no tecido digital precisa ser avaliada em novos estudos.

Palavras-chave: Bovinos. Casco. Macrominerais. Microminerais. Pododermatite asséptica.

Foot disorders are among the diseases that most affect the health and welfare of animals, and it is estimated that they cause economic losses of up to $40 \%$ in dairy cows (NICOLETTI, 2004). The incidence of diseases causing claudication in bovines has increased greatly in recent years, and claudication resulting from foot disorders is considered a major problem in dairy cattle. Lame cows reduce their food intake due to pain and reluctance to move, and may have a decrease in milk production of up to $1.5 \mathrm{~kg} \mathrm{day}^{-1}$, or from 5 to $20 \%$ of lactation milk production (SILVA et al., 2004).

Most locomotor system injuries are associated with poor hoof quality and loss of elasticity, hardness, tissue composition, hygroscopic properties, and misalignment of the horny capsule (MENDES et al., 2013). Nutrition is directly related to the quality of hoof horny tissue and the occurrence of digital disorders in cattle. Horny capsule development and quality of configuration are influenced by nutritional deficiencies and unfavorable environmental conditions, with increased sole wear and susceptibility to digital lesions (BALLANTINE et al., 2002). However, little is known about the role of some macro- and microminerals in the keratinization process of this tissue.

Hoof capacity for standing environmental conditions depends mainly on the physical properties of hardness, resistance, and viscoelasticity, which are determined by the chemical composition (BAGGOTT et al., 1988; WINKLER; MARGERISON, 2012). It is believed that mineral concentration is directly associated with the integrity of keratinized tissues, and therefore may affect tissue quality. Thus, increased bioavailability of minerals results in improvement in horny tissue (BALLANTINE et al., 2002).

Tissue bioavailability and retention of minerals have been demonstrated in many studies, revealing the importance of these elements in the metabolism of different systems involved in biochemical, hormonal, oxidative, and enzymatic processes. Some studies have reported the importance of zinc, calcium, magnesium, and phosphorus in dairy production and bovine fertility; however, studies on the effects of these macro- and microelements in hoof integrity remain scarce.

Nevertheless, in some foot disorders a complete absence of chemical synthesis or changes in bonding of keratin and structural proteins of the hoof may be presented, with resulting deterioration in macromolecular organization, along with changes in mechanical strength needed for movement of the digit on soil (WINKLER; MARGERISON, 2012).

The most common foot disorder in bovines is laminitis, defined as aseptic diffuse inflammation of hoof layers promoting degeneration and necrosis of lamellar tissue. These changes predispose animals to a number of lesions associated with this disease, including hemorrhage, sole ulcers, and white line disease.

Thus, despite great progress in research in recent years, the pathophysiology of locomotor diseases in dairy cattle is not fully clarified, given that inflammatory and metabolic events may influence the concentration of inorganic elements, thus interfering with the formation and integrity of the hoof. 
Bicalho et al. (2007) reported an inverse relationship between body condition score (BCS) and locomotor diseases, and described the positive association between digital cushion thickness and the effect of soil on the digit; in other words, the lower the BCS, the higher the biomechanical stress induced by the soil on the digit, thus contributing to claudication. However, they did not relate these disorders to the levels of minerals in the hoof horny capsule.

Thus, this study aimed to evaluate mineral concentration in the horny capsule of Holstein dairy cow hooves. Both healthy and lame cows with foot lesions associated with laminitis were studied.

Twenty-one multiparous, Holstein cows were studied, with $24 \mathrm{~L} \mathrm{day}^{-1}$ average milk production, under conditions of semi-extensive feeding management. The animals were assessed for locomotion score (LS), ranging from 0 to 4, where 0 represents the absence of gait abnormalities and 4 represents severe lameness (WINCKLER; WILLEN, 2001). The cows were divided into two groups: 11 with LS greater than 2, representing lesions associated with laminitis (lame cow group: LC), according to the method of Mendes et al. (2013), and 10 healthy cows (cows without laminitis: CWL), with $\mathrm{LS}=0$. In a clinical examination of the locomotor system conducted by veterinarians, all animals in the LC group presented lesions in the distal portion of the podal system (hoof). All cows in the LC group had at least 2 lesions associated with laminitis.

A single corneal tissue collection, with an area of approximately $30 \mathrm{~mm}^{2}$, was carried out in accordance with the method of Baggott et al. (1988); the sample weighed at least $3 \mathrm{~g}$, and was from the abaxial hoof wall. The sample was collected from an injured hoof in animals in the LC group and randomly in cows of the CWL group, using a loop hoof knife to a depth of approximately $4 \mathrm{~mm}$. Analysis of micro- and macrominerals was performed on these samples, following methodology for evaluation of minerals in horny tissue (HORWITZ, 1980), for calcium, phosphorous, zinc, and magnesium levels.

Blood sampling was conducted simultaneously with hoof sampling by arteriovenous coccygeal complex puncture, using an evacuated test tube with no anticoagulant. The samples were then centrifuged for total calcium determination with a spectrophotometer.

No animals in this study received prophylactic or therapeutic treatment for orthopedic diseases.

This study was approved (number 6243) by the Ethics Commission on Animal Use at the Federal University of Pelotas.

Statistical analysis was performed using Statistix 8.0 software. The data were analyzed using the Shapiro-Wilk normality test and/or WilcoxonMann-Whitney test in the absence of normal distribution between variables in order to evaluate nonparametric measurements when comparing two independent groups. Pearson's correlation test was used to determine the correlation between the concentration of minerals in cows with and without foot disorders.

The most common hoof lesions (Table 1) were sole ulcers $(25 \%)$, white line disease $(20 \%)$, sole bleeding (15\%), and stress lines (15\%); the results were similar to those found by Mendes et al. (2013), in which stress lines had the highest incidence in the hoof wall, followed by white line disease and sole bleeding.

White line disease is the disorder most commonly associated with subclinical laminitis, which is the most common disorder in dairy cows. The disorder is difficult to diagnose in podal lesions that do not present with clinical signs of pain, and is linked to other complications such as abscesses, sole separation, wall fissures, enlargement, and sole bleeding, which are consequences of changes in the quality of the stratum corneum and in hoof white line thickness (MÜLLING, 2002). 
On comparing mineral concentrations in the horny tissue of hooves in this study, a difference between the groups was noted for magnesium concentration $(\mathrm{P}=0.008)$, but not for calcium, phosphorous, and zinc $(\mathrm{P}>0.05)$ (Table 2).

Table 1. Lesions associated with laminitis in lame cows.

\begin{tabular}{lcc}
\hline \multicolumn{1}{c}{ Lesions } & $\begin{array}{c}\text { Number of } \\
\text { observations }\end{array}$ & $\begin{array}{c}\text { Percentage } \\
(\%)\end{array}$ \\
\hline Sole ulcer & 5 & $25 \%$ \\
White line disease & 4 & $20 \%$ \\
Sole bleeding & 3 & $15 \%$ \\
Stress lines & 3 & $15 \%$ \\
Toe ulcer & 2 & $10 \%$ \\
Scissor hoof & 1 & $5 \%$ \\
Sole abscess & 1 & $5 \%$ \\
Slipper hoof & 1 & $5 \%$ \\
Total & 20 & $100 \%$ \\
\hline
\end{tabular}

Table 2. Concentration of minerals in the horny tissue (average \pm standard deviation) of cows with (LC) and without (CWL) laminitis.

\begin{tabular}{lccc}
\hline & $\mathrm{LC}\left(\mathrm{mg} \mathrm{kg}^{-1}\right)$ & $\mathrm{CWL}\left(\mathrm{mg} \mathrm{kg}^{-1}\right)$ & P Value \\
\hline Calcium & $8.5 \pm 0.44$ & $13.7 \pm 0.76$ & 0.06 \\
Zinc & $12.0 \pm 5.45$ & $10.0 \pm 2.57$ & 0.41 \\
Magnesium & $7.5 \pm 0.55^{\mathrm{b}}$ & $14.8 \pm 0.26^{\mathrm{a}}$ & 0.008 \\
Phosphorus & $9.9 \pm 1.37$ & $12.3 \pm 0.72$ & 0.41 \\
\hline
\end{tabular}

Serum calcium concentrations did not differ between the LC and CWL groups, at $9.23 \pm 1.2 \mathrm{mg}$ $\mathrm{dL}^{-1}$ and $10.60 \pm 1.3 \mathrm{mg} \mathrm{dL}^{-1}$, respectively $(\mathrm{P}>0.05)$; these were within normocalcemic reference values for the species (MARTINEZ et al., 2012). It is known that differentiation of epidermal cells is very sensitive to changes in plasma calcium levels. In animals with hypocalcemia, Mülling et al. (1999) identified corneal tissues with deficient keratinization, indicating the influence of calcium on the differentiation of epidermal cells. Killic et al. (2007) evaluated the mineral profile of both lame and healthy cows and also identified normocalcemic animals; however, lower phosphorous and zinc serum concentrations were measured in lame cows, demonstrating the deficiency of these minerals not only in the horny tissue but also in serum levels.

Animals in the LC group showed a trend $(\mathrm{P}=0.06)$ for lower calcium concentrations compared to healthy cows (CWL) (Table 2), although blood levels were similar $(\mathrm{P}>0.05)$. According to Mülling et al. (1999) there is a relationship between calcium concentration in the horny tissue and production of keratinocytes, promoting the activation of epidermal transglutaminase, which participates in the bonding process between keratin fibers of the cell envelope and the final differentiation of epidermal cells. Casagrande (2013) reported that hypocalcemic animals show higher hoof wall wear than normocalcemic animals, thus demonstrating the effect of calcium concentration in podal metabolism. There is some speculation that normocalcemia and mild deficiency of calcium ion $(\mathrm{P}=0.06)$ in horny tissue may be related to circulatory insufficiency in the digital tissue of cows affected by laminitis; when associated with lower local magnesium concentrations identified in this study $(\mathrm{P}=0.008)$, taking into account the enzymatic cofactor functions, these findings would contribute to the occurrence of the podal changes identified.

Cows in the LC group showed lower magnesium concentrations in the horny tissue than those in the CWL group $(\mathrm{P}=0.008)$. Few reports have emphasized the direct influence of magnesium concentration on hoof formation. However, the influence of magnesium on calcium homeostasis is well known, and is important in keratogenesis (MÜLLING et al., 1999).

Magnesium plays an important role in calcium homeostasis, and primarily affects its metabolism in 2 different ways. The first is by reducing parathormone secretion and the second is by reducing the sensitivity of the tissues to this hormone. In cows with hypomagnesemia, even in the presence of hypocalcemia, the concentrations of parathormone did not increase, leading to 
the conclusion that magnesium is essential for parathormone release as well as for the synthesis of 1,25-dihydroxyvitamin D (LEAN et al., 2006). The effect of decreased magnesium concentration on tissue sensitivity to parathormone occurs because it activates adenylyl cyclase when bound to a receptor in the bone and kidney, leading to the production of the second messenger cyclic AMP. In other tissues, the parathormone receptor activates phospholipase $\mathrm{C}$, leading to the formation of the second messengers diacylglycerol and inositol 1,4,5-trisphosphate.

Mülling (2002) showed the importance of the relationship between the zinc and calcium complex for hoof structure. In this study, cows from the LC group exhibited a negative correlation between these minerals $(\mathrm{r}=-0.71 ; \mathrm{P}=0.02)$, demonstrating that animals with lower calcium levels had higher zinc concentrations. This negative correlation suggests that lame and injured cows may have a deficit in the final differentiation of epidermal cells in corneal tissue, taking into account the interaction between these minerals, in which zinc participates in the keratinization process and calcium in cornification and final differentiation of epidermal cells (MÜLLING et al., 1999). Therefore, these results indicate that the calcium-dependent cornification process must be impaired.

Although no differences in zinc concentration between the groups were noted $(\mathrm{P}=0.446)$, this mineral is a major component of the keratinization processes, playing a fundamental role in the formation of hoof structural proteins (MÜLLING, 2002). Cows with insufficient zinc concentrations present with deficient formation of keratin filaments and decreased keratinocyte development (BALLANTINE et al., 2002). Baggott et al. (1988) reported that lame cows have lower zinc concentrations than healthy cows and more sensitive horny tissue, indicating zinc or vascular insufficiency. Several proposals have been made for the supplementation of dietary minerals in production systems with a high incidence of podal disorders. Ballantine et al. (2002) studied cows fed with organic sources of zinc, and identified fewer locomotion disorders related to the hoof.

Phosphorus concentrations did not differ between the groups $(\mathrm{P}=0.416)$ and Penev et al. (2014) found no relationship between hoof hardness and concentration of this macroelement in the horny tissue, even though Baggott et al. (1988) reported higher hoof wall resistance in animals with higher phosphorus concentrations. Casagrande (2013) concluded that cows with high serum phosphorus concentrations exhibited healthier and stronger hooves, which was related to greater keratin synthesis.

Analysis of mineral concentrations in horny tissues of dairy cows can provide objective indexes of metabolic health and foot strength assessment (PENEV et al., 2014). Some changes in the mineral profile of animals in this study require clarification; as stated by Baggott et al. (1988), we must consider not only changes in mineral concentration, but also cell disorders, pathological changes, poor absorption of these components in the diet, and even metabolic disorders. It is relevant to consider the influence of other variables in this context, including the environment, management, nutrition, conformation, lactation phase, and age range, in view of their strong effects on hoof integrity (MENDES et al., 2013).

An important factor to consider in the mineral constitution of the hoof is the hygroscopic capacity of the podal horny tissue. Hence, we highlight the possibility of absorption of not only soil water by the hoof, but also other constituent macro- and microelements that affect concentration in the tissue, and can be influenced by season, rainfall, and the management system being used. In this study, horny tissue samples were collected in a wet season, with rainfall of about $100 \mathrm{~mm}$ per month. This could account for possible interference and variability in the results of podal tissue composition. 
The soil where the animals were located had sandy and clayey characteristics, depending on which lot these animals occupied.

Although the concentrations of serum calcium and the results in horny tissue did not vary between the LC and CWL groups, future studies analyzing such relationships and the interaction of these systemic components with digital tissue must be explored, taking into account metabolic levels, serum mineral profile, nutritional level, and degree of digital impairment.

\section{Acknowledgements}

The authors acknowledge the Coordenadoria de Aperfeiçoamento de Pessoal de Nível Superior (CAPES), the Fundação de Amparo à Pesquisa do Estado do Rio Grande do Sul (FAPERGS), and the Conselho Nacional de Desenvolvimento Científico e Tecnológico (CNPQ) for financial support, and Granja 4 Irmãos for assistance with the project.

\section{References}

BAGGOTT, D. G.; BUNCH, K. J.; GILL, K. R. Variations in some inorganic components and physical properties of claw keratin associated with claw disease in the british friesian cow. British Veterinary Journal, London, v. 144, n. 6, p. 534-542, 1988.

BALLANTINE, H. T.; SOCHA, M. T.; TOMLINSON, D. J.; JOHNSON, A. B.; FIELDING, A. S.; SHEARER, J. K., VAN AMSTEL, S. R. Effect of feeding complexed zinc, manganese, copper and cobalt to late gestation and lactating dairy cows on claw integrity, reproduction and lactation performance. The Professional Animal Scientist, Champaign, v. 8, n. 3, p. 211-218, 2002.

BICALHO, R. C.; VOKEY, F.; ERB, H. N.; GUARD, C. L. Visual locomotion scoring in the first seventy days in milk: Impacto $\mathrm{n}$ pregnancy and survival. Journal of Dairy Science, Missouri, v. 90, n. 10, p. 4586-4591, 2007.

CASAGRANDE, F. P. Perfil metabólico e mineral de vacas no periodo peri-parto: qualidade e conformação dos cascos. 2013. Tese (Doutorado em Ciência Animal) - Curso de Pós-Graduação em Ciência Animal. Universidade Federal de Minas Gerais, Belo Horizonte.
HORWITZ, W. (Ed.). Official methods of analysis of the association of official analytical chemists. $13^{\text {th }}$ ed. Washington: AOAC, 1980. 384 p.

KILLIC, N.; CEYLAN, A.; SERIN, I.; GÖKBULUT, C. Possible interaction between lameness, fertility, some minerals, and vitamin E in dairy cows. BulletinVeterinary Institute Pulawy, Pulawy, v. 51, n. 1, p. 425429, 2007.

LEAN, I. J.; DeGARIS, P. J.; McNEIL, D. M.; BLOCK, E. Hypocalcemia in dairy cows: meta analysis and dietary cation anion difference theory revisited. Journal of Dairy Science, Missouri, v. 89, n. 2, p. 669-684, 2006.

MARTINEZ, N.; RISCO, C. A.; LIMA, F. S.; BISINOTTO, R. S.; GRECO, L. F.; RIBEIRO, E. S.; MAUNSELl, F.; GALVÃO, K.; SANTOS, J. E. P. Evaluation of peripartal calcium status, energetic profile, and neutrophil function in dairy cows at low or high risk of developing uterine disease. Journal of Dairy Science, Missouri, v. 95, n. 12, p. 7158-7172, 2012.

MENDES, H. F; CASAGRANDE, F. P.; LIMA, I. R.; SOUZA, C. H.; GONTIJO, L. D.; ALVES, G. E. S.; VASCONCELOS, A. C.; FALEIROS, R. R. Histopathology of dairy cows hooves with signs or naturally acquired laminitis. Pesquisa Veterinária Brasileira, Seropédica, v. 33, n. 5, p. 613-619, 2013.

MÜLLING, C.; BRAGULLA, H.; REESE, S. How structures in bovine hoof epidermis are influenced by nutritional factors. Anatomia, Histologia, Embryologia, Berlin, v. 28, n. 2, p. 103-108, 1999.

MÜLLING, C. K. W. 2002. Theories on the pathogenesis of white line disease - an anatomical perspective. In: INTERNATIONAL SYMPOSIUM ON LAMENESS IN RUMINANTS, 12., 2002, Orlando. Anais eletrônicos... Orlando: [s.n.], 2002. p. 90-98..

NICOLETTI, J. L. M. Manual de podologia bovina. Barueri: Manole, 2004, 126 p.

PENEV, T.; ILIEV, A.; MITEVA, C. H.; MITEV, Y.; VALKOVA, P.; UZUNOVA, K. Investigation of manureinduced physicochemical changes of the claw horn in dairy cattle. Journal of The Faculty of Veterinary Medicine Istanbul University, Istanbul, v. 40, n. 1, p. 4152, 2014.

SILVA, L. A. F.; FIORAVANTI, M. C. S.; TRINDADE, B. R.; SILVA, O. C.; EURIDES, D.; CUNHA, P. H. J.; SILVA, L. M.; MOURA, M. I. Enfermidades digitais em vacas de aptidão leiteira: associação com mastite clínica, metrites e aspectos epidemiológicos. Pesquisa Veterinária Brasileira, Seropédica, v. 24, n. 4, p. 217 222, 2004. 
WINCKLER, C.; WILLEN, S. The reliability and repeatability of a lameness scoring system for use as an indicator of welfare in dairy cattle. Acta Agriculture Scandinavia, London, v. 51, n. 30, p. 103-107, 2001.
WINKLER, B.; MARGERISON, J. K. Mechanical properties of the bovine claw horn during lactation. Journal of Dairy Science, Missouri, v. 95, n. 4, p. 17141728, 2012. 
